\title{
Profile of albinism with low vision and improvement of visual acuity with the adaptation of optical and / or electronic resources
}

\author{
Perfil do paciente albino com visão subnormal \\ e melhoria da acuidade visual com a adaptação \\ de recursos ópticos e/ou eletrônicos
}

Diego Fleury de Lemos Pereira1, Evandro Lopes Araujo², Fernanda Viana Duarte Patuzzo²

\begin{abstract}
Objective:Determine the profile of albinism in Low Vision Department of Benjamin Constant Institute. Highlight the follow-up, the frequency of follow-up, and the visual improvement with the adaptation of optical and / or electronic resources. Methods: A retrospective study with data from 77 patients with ocular albinism aged 1- 53 years old attended at Benjamin Constant Institute between 2003 and 2014. Results: The most suitable optical feature is the telescope Galilleu 2.8x. All patients reported gain vision with the resources. Most patients experienced visual acuity with optical devices between 20/25 - 20/160. Conclusion: Optical resources assisted in the improvement of visual function and quality of life of patients with ocular albinism.
\end{abstract}

Keywords: Albinism, ocular; Vision, low; Visual acuity; Nistagmus

\section{ReSUMO}

Objetivo: Determinar o perfil do paciente albino no departamento de visão subnormal do Instituto Benjamin Constant. Ressaltar o tempo de acompanhamento, a frequência do seguimento, e a melhora visual com a adaptação de recursos ópticos e/ou eletrônicos. Métodos: Estudo retrospectivo com dados de 77 pacientes albinos com idade entre 1 a 53 anos de idade atendidos no Instituto Benjamin Constant, entre 2003 e 2014. Resultados: O recurso óptico mais adaptado foi o telescópio de Galilleu 2.8x. Todos os pacientes referiram ganho de visão com os equipamentos. A maioria dos pacientes apresentaram acuidade visual com recursos ópticos entre 20/25 e 20/160. Conclusão: Os recursos ópticos auxiliaram na melhora da função visual e na qualidade de vida dos pacientes com albinismo ocular.

Descritores: Albinismo ocular; Baixa visão; Acuidade visual; Nistagmo

\footnotetext{
${ }^{1}$ Universidade Federal Fluminense - Niterói, (RJ), Brasil;

2 Instituto Benjamin Constant - Rio de Janeiro, (RJ), Brasil.

The authors declare no conflicts of interests.

Received for publication 09/05/2016 - Accepted for publication 14/09/2016
} 


\section{INTRODUCTION}

A lbinism comes from the Latin albus, which meaning white, and is a group of hereditary disorders in which the biosynthesis of the pigment melanin is absent or reduced. Currently it is classified according to the gene affected, and no longer as partial or total, tyrosinase positive or tyrosinase negative. ${ }^{(1)}$ The gene for tyrosinase is in chromosome 11q14-21 and the $\mathrm{P}$ gene on chromosome 15q11.2 are most commonly affected genes, and mutations in these genes cause type 1 oculocutaneous albinism (OCA1; OMIM203100) and type 2 oculocutaneous (OCA2; OMIM 203200), respectively. These types of albinism are inherited in an autosomal recessive manner, and are expressed in both men and women. (2)

Mutations involving the OCA1 affect tyrosinase, whereas those responsible for the OCA 2 compromise a protein known as protein P. Contrary to what happens with the albino OCA1, tyrosinase in OCA2 is unchanged, but is compromised due to protein $\mathrm{P}$. This protein, responsible for the control of $\mathrm{pH}$, is found in the membrane of melanossomes, cellular organelles where melanin is stored. Melanossomal $\mathrm{pH}$ is of fundamental importance for the activity of tyrosinase. Brown Oculocutaneous albinism (BOCA) is an OCA2 category exclusive of Africans and African Americans. It is believed that this disorder is the result of a weak mutation expressed in reduced activity of the protein P. Hair and skin are light brown, the iris is gray, and visual acuity of 20/60 to $20 / 150$. Over time, the hair and iris darken, but the skin remains depigmented. Oculocutaneous albinism 3 (OCA3), formerly OCA red or casing, is caused by mutation in the gene encoding protein 1, tyrosinase-related (TRP1). As a result of mutation, there is a disruption of the tyrosinase, and a brown pigment is synthesized instead of the black melanin. ${ }^{(3)}$

Another type of albinism caused by mutations in Xp22.is 3 ocular albinism (OA1; OMIM 300500) that affects men because of heritage linked to the chromosome X. Other types of albinism occur more rarely, including those associated to systemic manifestations, like Hermansky-Pudlak syndrome (OMIM 203300; bleeding disorder due to the absence of dense bodies in platelet) and Chediak Higashi syndrome (OMIM 214500; immunodeficiency and neurological problems). The prevalence of albinism in the United States is estimated in 1 in every 18.000 individuals. (2)

Due to ethical issues, laboratory tests for the diagnosis of albinism should be offered only to families that have cases of albinism, not being indicated as methods of screening of the general population in relation to the condition. Prenatal diagnosis can be performed with material obtained by amniocentesis, between the 16th and 18th weeks of pregnancy, providing early clarification to the family and appropriate support to the child with albinism, which typically does not present major development disorders. ${ }^{(3)}$

There are two types of melanin, eumelanin (black and brown) and phaeomelanin (yellow and red), and the biosynthesis of the two melanins follow different routes. Tyrosinase is involved in the first two steps of the synthesis of pigments, and from Dopaquinon the melanin formed can be eumelanin or phaeomelanin (Figure 1). Although the oxidation of tyrosine by tyrosinase is required for the synthesis of both types of pigments, the activation of melanocortin 1 receptor (MC1R) promotes the synthesis of eumelanin at the expense of phaeomelanin. ${ }^{(3)}$

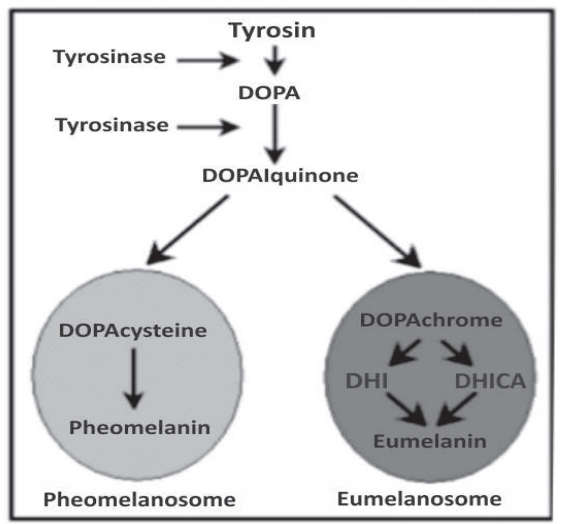

Figure 1: metabolic pathways in the synthesis of melanin

Oculocutaneous albinism occurs in the general frequency of 1 in 15,000 in all racial groups. It affects people of all ethnicities, although OCA2 is more frequent in black people. OCA1 occurs in about one in 40000 individuals in most populations. OCA2 is more frequent in African-Americans and Africans, occurring 1 in 10000 of those individuals, while in Caucasians the frequency is estimated to be 1 in 36000 . $(15,16)$

The cutaneous phenotype often allows the diagnosis to be made. However, foveal hypoplasia is common to all types of albinism, although a rudimentary ring reflex has been described in some patients with better visual acuity. Brothers with albinism can show variable expression in the visual function and clinical phenotype, suggesting that other genes can modify the phenotypic ocular findings. Ocular findings do not allow determining the type of albinism. ${ }^{(4)}$

Late visual maturation was reported in albinism. ${ }^{(5)}$ It is not usual for parents of a child with albinism to notice the difficulty in fixing faces and objects, and a delay in visual maturation. Nystagmus develops typically between 6 to 8 weeks of life. If the phenotype of albinism is not recognized, patients can undergo neurological exam, including functional magnetic resonance imaging of the brain, before the diagnosis of albinism, with no abnormalities detected. ${ }^{(6)}$ The neurological development was carefully measured in 78 children with albinism from 4 to 18 years, and it was considered normal, despite the reduced visual acuity. Some cases are associated to hyperactivity and attention deficit. $^{(7)}$

The ocular findings are discreet exotropia, reduced or absent foveolar development, decreased iridian pigments seen in transillumination. The amount of iris seen in transillumination can be graded as follows: grade 1, punctate areas of transillumination, indicating the pigments in the posterior region of iridian epithelium; grade 2, pigment of moderate iris; grade 3 , minimum iridian pigment; and grade 4, full iridian transillumination because of the absence of the pigment melanin. The appearance of the macula was classified as follows: grade 1, choroidal vessels easily seen in the macula; grade 2 , the choroidal vessels less clearly seen because of the translucent retinal pigment epithelium; and grade 3, not visible vessels. ${ }^{(8)}$

According to the International Council of Ophthalmology(9), far sight visual acuity can be referred to as normal if it is greater than or equal to $20 / 25$ (0.8); mild loss of sight is between 20/25 (0.8) and 20/60 (0.3); moderate loss between 20/60 (0.3) and 20/ 160 (0.125); severe loss between 20/160 (0.125) and 20/400 (0.05); deep loss of sight between 20/400 (0.05) and 20/1000 (0.02); almost 
total loss of sight (blindness) between 20/1000 (0.02) and perception of light; and total loss of sight (blindness) without perception of light. This is the classification we use in our study.

\section{Methods}

We conducted a retrospective study comprised of albino individuals attended at Instituto Benjamin Constant, in Rio de Janeiro, between 2003 to 2014, with 77 patients with ocular or oculocutaneous albinism living in the State of Rio de Janeiro. In the study, we seek to identify which optical feature was more adapted, providing improved visual acuity for both near and far sight.

Were assisted individuals living in the cities of Rio de Janeiro, Itaguai, Barra Mansa and Volta Redonda. A total of $77.9 \%$ of patients lived in Rio de Janeiro. Our study met the patients referred to Instituto Benjamin Constant, a reference service in the care of patients with low vision.

The following variables were used: sex, age group, optical feature prescribed for far sight, optical feature prescribed for near sight.

\section{ResUlts}

The results obtained were expressed as follows: Gender (Figure 2); Age (Figure 3); Visual acuity for far sight with optical feature (Figure 4); Visual acuity for far sight with correction (Figure 5); Visual acuity for near sight with correction (Figure 6); Visual acuity for near sight with optical feature (Figure 7); Presence of nystagmus (Figure 8); Ametropias (Figure 9); Optical or electronic resources prescribed (Figure 10);

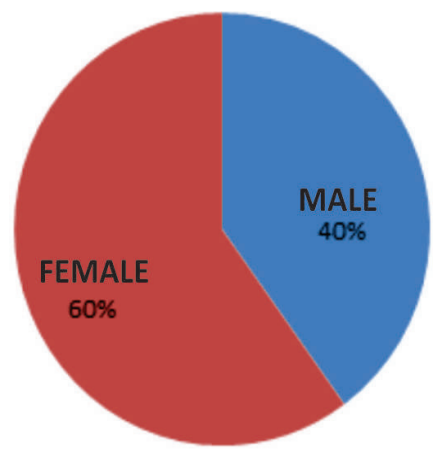

Figure 2: Distribution according to the sex of the patients

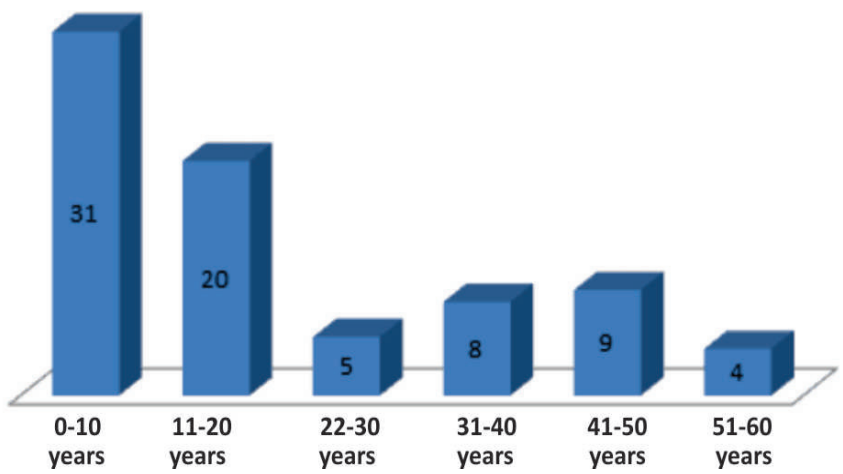

Figure 3: Distribution according to the age of the patients:

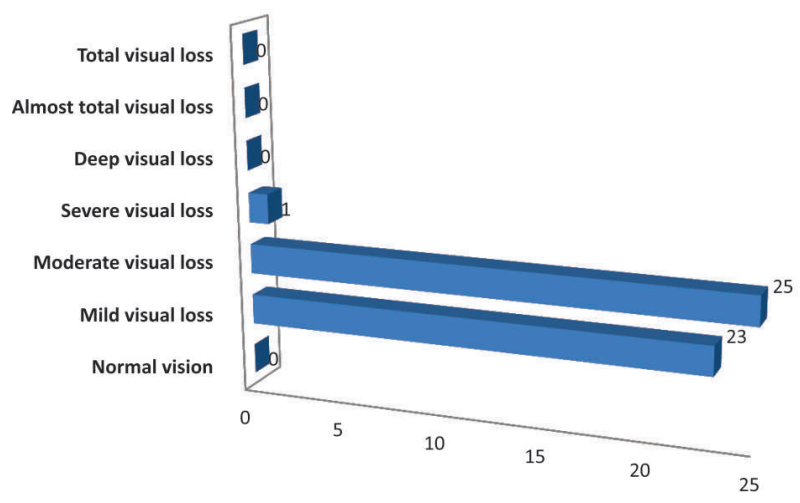

Figure 4: Visual acuity for far sight with optical feature

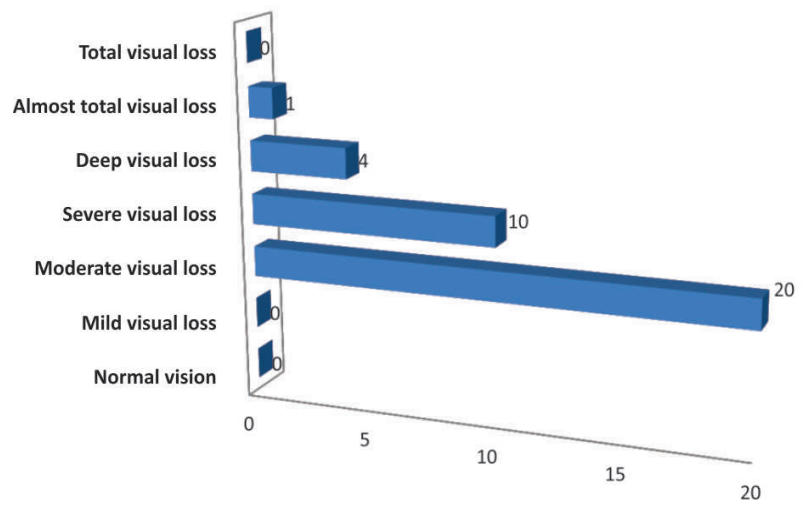

Figure 5: Visual acuity for far sight with correction

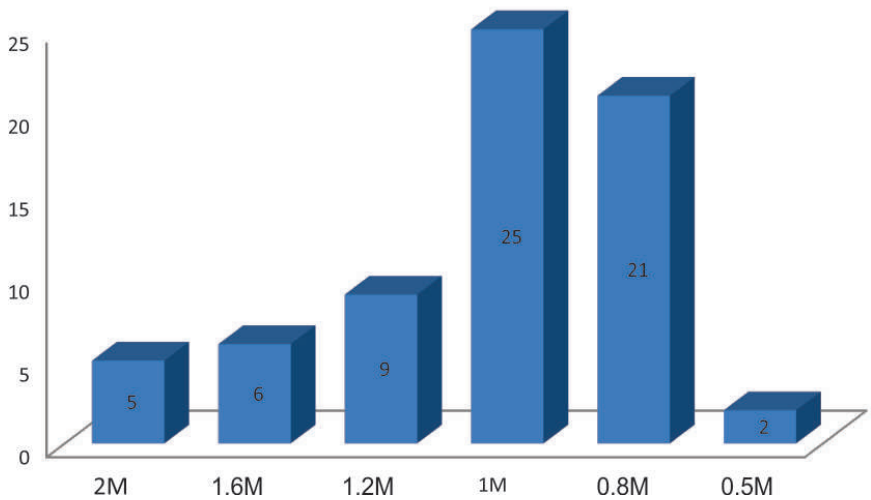

Figure 6: Visual acuity for near sight with correction

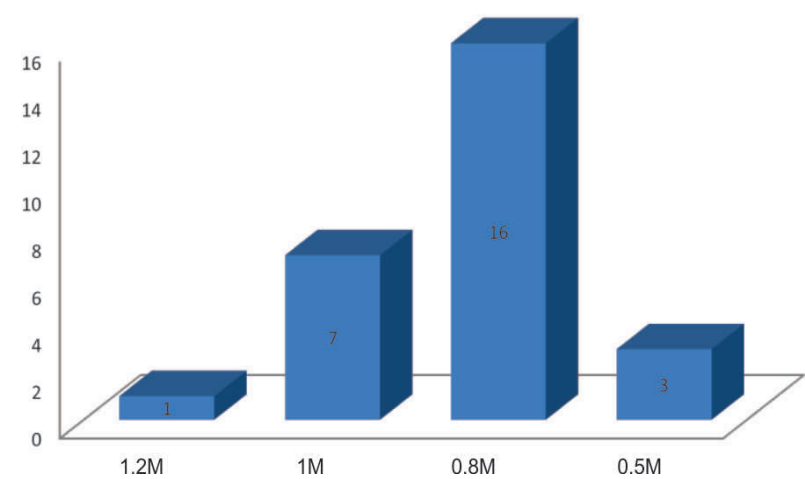

Figure 7: Visual acuity for near sight with optical feature 


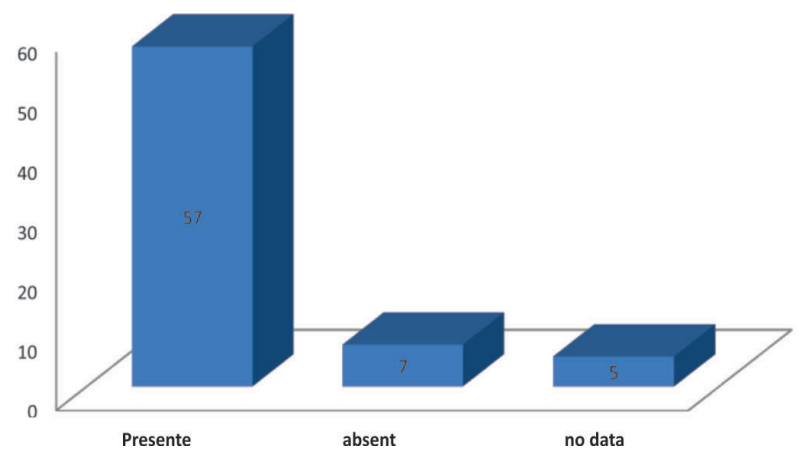

Figure 8: Nystagmus

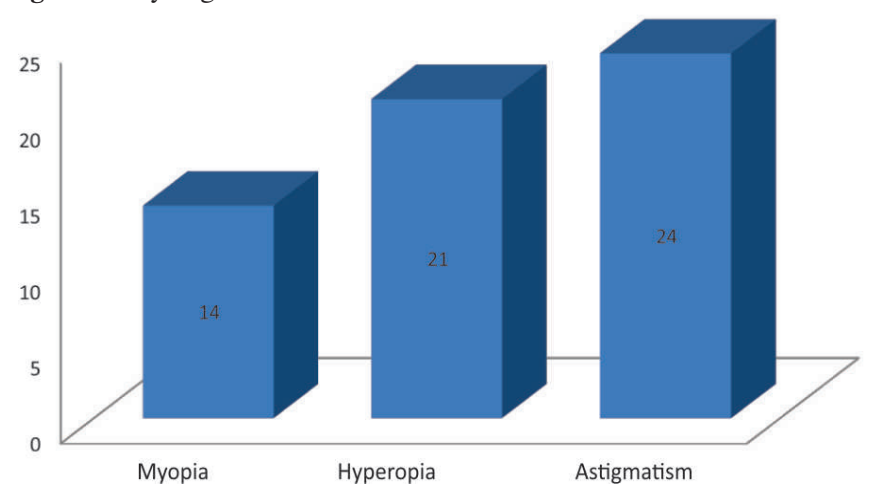

Figure 9: Ametropias

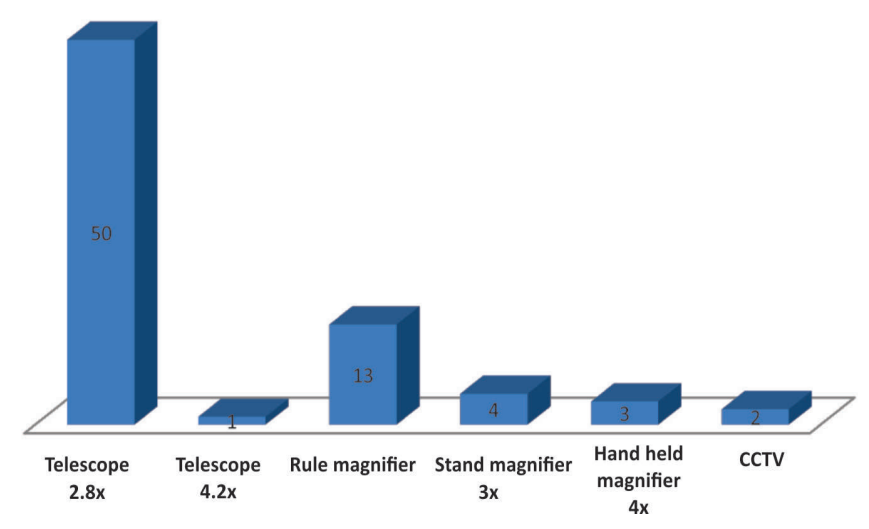

Figure 10: Optical or electronic resources prescribed

\section{Discussion}

In view of the data exposed, we realized that $62.33 \%$ of the patients have significantly improved visual acuity with optical features in mild or moderate loss of sight. The Galilean telescope $2.8 \mathrm{x}$ was the optical feature more often adapted, in $70 \%$ of patients. In patients between $0-20$ years, the adaptation of this feature was of $68 \%$. A greater number than in the study of 2001 , carried out with children from 4-16 years, in which telescopes were prescribed to $30 \%$ of patients ${ }^{(10)}$ This shows the need to adapt features at school age for the best learning. We know that it is important to stimulate the use of the feature that is often abandoned by the child.

The average visual acuity for far sight with the feature was around 0.7, a similar value to a study with albino patients of 1996.
This shows us that it is extremely important to test the features calmly on patients with low vision because the visual improvement is substantial. ${ }^{(11)}$

The first care in 26 patients was late, after 20 years of age. Considering that the IBC offers a differentiated service and is prepared to assist children and youngsters, we have reinforced the need to refer patients with low vision as early as possible. In addition, various studies, such as the one from Sweden in 2001 about causes of amblyopia ${ }^{(12)}$, show that ocular albinism is more common than previously believed. It also generates amblyopia, and its consequences are very harmful to the lives of children.

The study from New England from 2001 about albino patients from Puerto Rico relating genetic changes (16bp duplication in exon 15) and restrictive lung disease ${ }^{(13)}$ is also worth to be mentioned because it shows us that other genetic changes not yet discovered can assist us in early detection and in the most appropriate care of patients.

Most patients have improved visual acuity both far and near sight with the optical features prescribed. Hence the importance of knowledge and the use of optical features for patients with albinism or with low vision.

It is irrefutable the scarcity of studies showing the improvement in visual acuity of all patients with low vision. We hope that in the future we will have more jobs related to this subject, to the extent that the optical features greatly improve the quality of life of these people.

\section{Conclusion}

While creating the albino patient profile at Instituto Benjamin Constant we tried to analyze which is the most appropriate optical feature and which visual acuity was achieved in each case. Thus, we plan to contribute more effectively with greater visual efficiency of albino patients, since many of them show a significant visual impairment. Knowing the optical features that the albino benefits, we can improve their quality of life. The results of our study exemplify the benefit that many patients have with optical devices.

It is undeniable the need for new health policies to improve the quality of life for individuals with low vision. Making optical features more accessible and available to the population, educating and training professionals in the field of low vision are extremely important measures to improve the quality of life of all this population.

\section{ReferenCes}

1. Summers CG, Oetting WS, King RA. Diagnosis of oculocutaneous albinism with molecular. Am J Ophthalmol. 1996;121(6):724-6.

2. Gail S. Albinism: Classification, clinical characteristics, and recent findings. Optom Vis Sci. 2009; 86(6):659-62.

3. Lília MM, Shirlei CM, Lago TDC, Luciane MR. Perfil do albinismo oculocutâneo no estado da Bahia. Rev Cir Méd Biol 2007;6(1):69-75.

4. Cheong PY, King RA, Bateman JB. Oculocutaneous albinism: variable expressivity of nystagmus in a sibship. J Pediatr Ophthalmol Strabismus. 1992;29(3):185-8.

5. Fielder AR, Russell-Eggitt IR, Dodd KL, Mellor DH. Delayed visual maturation. Trans Ophthalmol Soc UK. 1985;104(Pt 6):653-61.

6. Oetting WS, Summers CG, King RA. Albinism and the associated ocular defects. Metab Pediatr Syst Ophthalmol (1985). 1994;17(14):5-9. 
7. Kutzbach BR, Summers CG, Holleschau AM, MacDonald JT. Neurodevelopment in children with albinism. Ophthalmology. 2008;115(10):1805-8, 1808.e1-2.

8. Summers CG, Knobloch WH, Witkop CJ Jr, King RA. HermanskyPudlak syndrome.Ophthalmic findings. Ophthalmology. 1988;95(4):545-54.

9. International Council of Ophthalmology. Visual standards: aspects and ranges of vision loss with emphasis on population surveys [Internet]. Report prepared for the International Council of Ophthalmology. Sydney, Australia, April 2002. [cited 2016 Sep 14]. Available from: http://www.icoph.org/downloads/visualstandardsreport.pdf

10. Shah M, Khan M, Khan MT, Khan MY, Saeed N. Causes of visual impairment in children with low vision. J Coll Physicians Surg Pak. 2011;21(2):88-92.

11. Sjödell L, Sjöström A, Abrahamsson M. Transillumination of iris and subnormal visual acuity-ocular albinism? Br J Ophthalmol. 1996;80(7):617-23
12. Ohlsson J, Villarreal G, Sjöström A, Abrahamsson M, Sjöstrand J. Visual acuity, residual amblyopia and ocular pathology in a screened population of 12-13-year-old children in Sweden. Acta Ophthalmol Scand. 2001;79(6):589-95.

13. Gahl WA, Brantly M, Kaiser-Kupfer MI, Iwata F, Hazelwood S, Shotelersuk V,Duffy LF, Kuehl EM, Troendle J, Bernardini I. Genetic defects and clinicalcharacteristics of patients with a form of oculocutaneous albinism(Hermansky-Pudlak syndrome). N Engl J Med. 1998;338(18):1258-64.

\section{Autor correspondente:}

Evandro Lopes Araujo

E-mail: evandrolopesaraujo@yahoo.com.br 